\title{
An Analysis of the Performance of Indian Engineering Goods Export
}

\author{
Asheref Illiyan*
}

\begin{abstract}
Engineering Sector has a place of pride in the Indian economy in terms of its contribution to output, employment and export. Engineering exports constitute roughly 20 per cent of total Indian export clocking very close to petroleum product export which is first in terms of overall Indian export. Engineering exports were valued at US \$71 billion in 2014-15. There has been a marked shift and change in the composition and destination of Indian engineering export over the years. Engineering sector has made its presence felt in the developed markets like US and European Union implying India's strength and capability to deliver quality products and face international competition. This paper is an attempt to analyse the performance of Indian engineering goods export in recent time during the period 2002-2015. Various dimensions of export such as export growth, destinations, composition, and problems of export and strategies of export are examined in the paper. The impact of the Global financial crisis of 2008 in US on engineering exports has been analysed through a dummy variable regression model.
\end{abstract}

Keywords: Engineering goods industry, Export, Regression model, Growth rate, Strategies for export promotion.

\subsection{Introduction}

Exports play an important role in the economic development of a country. It has been verified theoretically and empirically by many studies (Keesing, 1976; Michaely, 1977; Balassa, 1978; Kruger, 1978; Bhagawati and Srinivisan, 1979; Chow, 1987; Ghartey, 1993; Riezman et al., 1996). Broadly speaking, there is two way causality between export and economic growth. Export growth can promote economic growth and vice versa. The sustained and rapid economic growth of over 8 per cent by Four Asian Tigers since last 50 years and spectacular performance by Newly Industrialising Economies (NIEs) is classic example of success of export led growth strategy (Ahum Duk, Kong 2001).

*Senior Assistant Professor, Department of Economics, Jamia Millia Islamia. (e-mail: ailliyan@jmi.ac.in) 
India had been following an inward oriented and public sector dominated policy in the post-Independence period. Followed by a serious macroeconomic crisis in 1990-91, India switched over to an outward-oriented and private sector-oriented policy. The major part of this Structural Adjustment Policy (SAP) or new economic policy was industrial liberalisation, financial sector liberalisation, and trade liberalisation.

While trade liberalisation has led to a rise in exports over a period of time, there is still a long way to go as India's share in world exports is miniscule. The major exports from India for the year 2013-14 constitute agricultural and allied commodities (13.7\%), ores and minerals $(1.9 \%$ ), manufactured products $63.5 \%$ (such as engineering goods $(19.63 \%)$, gems and jewellery $(13.2 \%)$ and petroleum products $(20.12 \%)$. (Economic Survey, and DGCI\&S 2014).

In the present study, we propose to analyse the export performance of engineering Goods Industry in recent times (2002-2015). 2002-06 was period of booming economic activities all around the world reflected in higher world GDP growth, export and investment inflows. However, the period after 2008 witnessed great turmoil in economic activities due to US financial Crisis of 2007-08, followed by Eurozone crisis of 2013 and the China slowdown thereafter. While the GDP growth of the world has declined from 4.3 per cent in 2006 to 2.2 per cent in 2008 , it has declined much faster in advanced countries like the United States (from 2.8 per cent to 1.1. per cent) and the European Union (3.0 per cent to 0.7 per cent) (Table 1 and Figure 1).

Table 1: GDP Growth \%: 2006-08

\begin{tabular}{|l|l|l|l|l|}
\hline & World & United States & Euro Area (15) & $\begin{array}{l}\text { Advanced } \\
\text { Economies }\end{array}$ \\
\hline 2006 & 4.3 & 2.8 & 3.0 & 3.0 \\
\hline 2007 & 4.1 & 2.0 & 2.6 & 2.6 \\
\hline 2008 & 2.2 & 1.1 & 0.7 & 1.5 \\
\hline
\end{tabular}

"Along with the global slowdown in the growth of GDP, there has also been a substantial decline in world trade which may result in echo effects. The world real trade growth (corrected for prices) declined from 9.5 per cent in 2006 to 6.9 per cent in 2007 and further to 2.5 per cent in 2008. Amidst the global economic slowdown, the Organization for Economic Co-operation and Development (OECD) projects the global economy to grow by -2.7 per cent in 2009 and 1.2 per cent in 2010. The United States economy is expected to experience negative growth, i.e., -4 per cent in 2009 and 0 per 
cent growth in 2010. The EU area is expected to also experience a negative growth of 4.1 per cent in 2009 with a continued negative growth of -0.3 per cent in 2010 . China is expected to grow at 6.3 per cent and growth forecast for the Indian economy is at 4.30 per cent for the year 2009" (UNCTAD, 2013).

Figure 1: Slowdown in GDP Growth Rate, 2006-08

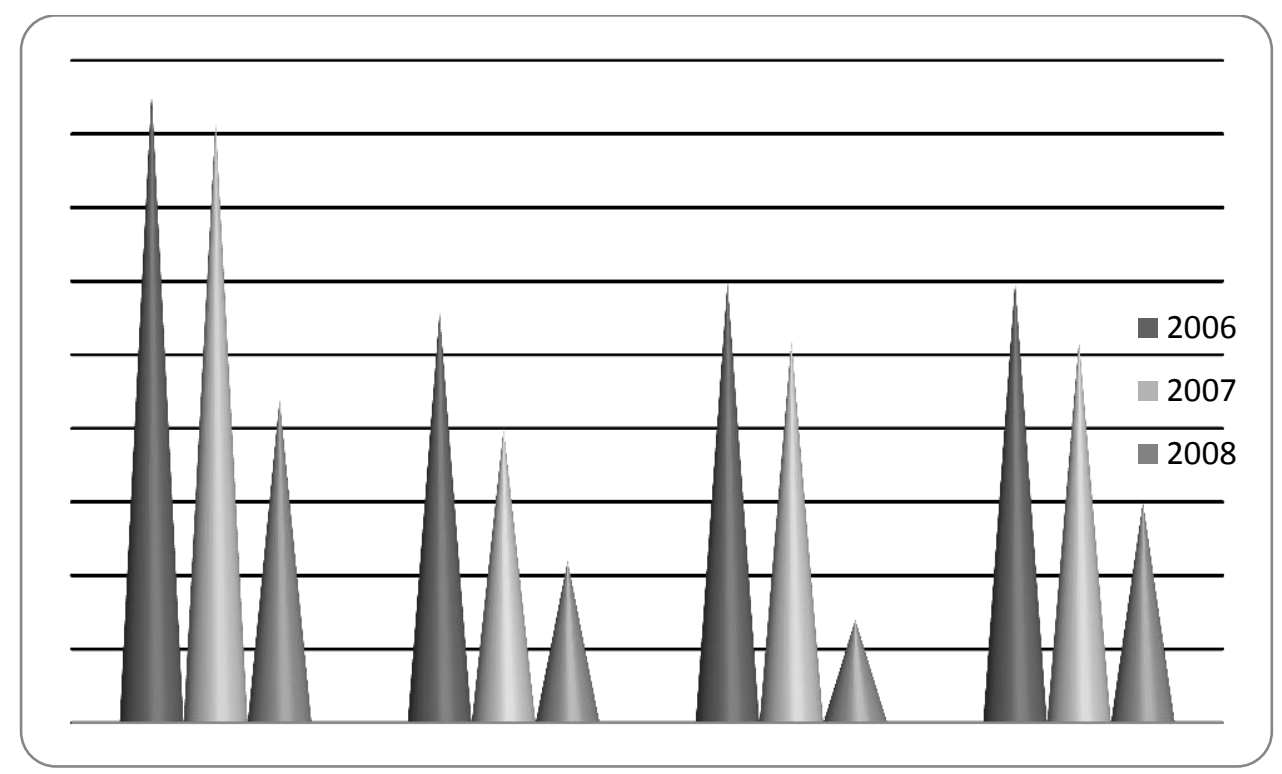

Source: OECD and IMF adapted from UNCTAD 2013

\subsection{Engineering sector in India}

According to Ministry of Commerce, Government of India definition, the engineering is a diverse sector encompassing a number of sub sectors related to the manufacturing from metals and their ores. It is a diverse industry with a number of segments, and can be broadly categorized into two parts, namely, heavy engineering and light engineering. There are however a number of sub sectors within the engineering sector namely iron and steel; other base metals and their products; mechanical machinery; electrical machinery; transport equipment (including automotives); instruments and appliances; time measuring instruments; musical instruments; arms and ammunition; and furniture and related articles.

In a country like India, the engineering sector which has witnessed unparalleled growth in the past few years plays a vital role for the development of other industrial sectors of the economy. India's engineering industry accounts for 27 per cent of the total 
factories in the industrial sector and represents 63 per cent of the overall foreign collaborations as on December 2013. Capacity creation in sectors such as infrastructure, power, mining, oil and gas, refinery, steel, automotive, and consumer durables are driving demand in the engineering sector. The engineering sector is the largest of the industrial sectors in India. India has a comparative advantage in some of the engineering sub sectors in terms of manufacturing costs, market knowledge, technology and creativity. The Government of India is also playing a crucial role in developing the engineering section of the economy. The engineering industry has been de-licensed and enjoys 100 per cent foreign direct investment (FDI). Further, the National Policy on Electronics is formulated by the Government of India to boost India's electronics systems and design the manufacturing industry and improve its share in the global market (Ministry of Commerce, GoI).

Above all, as per the data available for the year 2014-15, engineering industry has emerged as the second largest item of export with $19.63 \%$ share in total export clocking very close to petroleum products export whose share is $20.12 \%$ (See Table 2 for comparative share of different sectors in total export). Thus, engineering industry is reckoned as the engine of growth and development in Indian economy.

Table 2: Export of Principal Commodities Groups

(Values in Rs. Crores )

\begin{tabular}{|l|r|r|r|r|}
\hline \multicolumn{1}{|c|}{ Commodity } & Apr-Mar 2013 & Apr-Mar 2014 & \% Growth & \%Share \\
\hline A) Plantation & $9,429.86$ & $9,672.45$ & 2.57 & 0.51 \\
\hline $\begin{array}{l}\text { B) Agriculture \& allied } \\
\text { products }\end{array}$ & $174,194.01$ & $195,731.08$ & 12.36 & 10.27 \\
\hline C) Marine Products & $18,841.20$ & $30,627.28$ & 62.55 & 1.61 \\
\hline D) Ores \& Minerals & $30,597.00$ & $34,063.47$ & 11.33 & 1.79 \\
\hline E) Leather \& Mnfrs & $26,596.87$ & $34,679.98$ & 30.39 & 1.82 \\
\hline F) Gems \& Jewellery & $236,162.03$ & $252,175.14$ & 6.78 & 13.24 \\
\hline G) Sports goods & $1,125.33$ & $1,437.49$ & 27.74 & 0.08 \\
\hline $\begin{array}{l}\text { H) Chemicals \& Related } \\
\text { Products }\end{array}$ & $225,865.81$ & $266,453.03$ & 17.97 & 13.99 \\
\hline I) Engineering Goods & & & & \\
\hline J) Electronic Goods & $\mathbf{3 0 8 , 9 4 8 . 0 9}$ & $\mathbf{3 7 3 , 9 3 1 . 6 8}$ & $\mathbf{2 1 . 0 3}$ & $\mathbf{1 9 . 6 3}$ \\
\hline K) Project Goods & $45,970.26$ & $46,703.78$ & 1.60 & 2.45 \\
\hline L) Textiles & 780.80 & 291.22 & -62.70 & 0.02 \\
\hline M) Handicrafts & $143,444.81$ & $184,770.64$ & 28.81 & 9.70 \\
\hline N) Carpets & $1,110.29$ & $1,721.68$ & 55.07 & 0.09 \\
\hline O) Cotton Raw \& Waste & $20,374.22$ & $6,278.31$ & 16.82 & 0.33 \\
\hline P) Petroleum Products & $\mathbf{3 3 0 , 7 9 0 . 0 1}$ & $\mathbf{3 8 3 , 2 4 7 . 8 8}$ & $\mathbf{1 5 . 8 6}$ & $\mathbf{2 0 . 1 2}$ \\
\hline Q) Unclassified Exports & $54,811.74$ & $60,888.15$ & 11.09 & 3.20 \\
\hline Total & $1,634,318.83$ & $1,905,011.08$ & 16.56 & 100.00 \\
\hline
\end{tabular}

Source: DGCIS, Kolkata downloaded from DGFT website 
This paper is divided into seven sections. Introduction has been discussed in section 1. Section 2 discusses the review of related literature. The performance of Engineering industry in recent times 2002-2015, its share in total export, average annual growth rates, and regression model are narrated in Section 3. While item wise distribution of engineering export is attempted in section 4, section 5 explains destination of engineering export. Section 6 narrates the problems of engineering export along with strategy for export promotion and the role of Engineering Export Promotion Council and section 7 concludes.

\subsection{Review of Literature}

Nayyar (1976) emphasises that among new manufactures, engineering products gained importance in India's export basket during sixties, and within the engineering product mix diversified ranging from metal products and consumer items to industrial machinery and transport equipment. Kareem (1989) studies in detail the degree and magnitude of import substitution (IS) that has taken place in the Indian Engineering industry during the period 1970-84 and the relative contribution of IS to the output growth of the Engineering industry during the same period. The study shows that nearly 34 per cent of Engineering industry have attained clear positive IS and the remaining 66 per cent belong to either negative IS or no clear trend IS. The study reveals that IS's contribution to output growth is pronounced in those industries which have fared well in IS. However, compared to IS, the exports contribution is more significant in most of the industry groups. Furthermore, the study draws the interference that domestic demand pressure for imports slows the process of IS in the Engineering industry

Arora (1992) analyses the performance and problems of engineering export. The study covers the period from 1956-57 to 1992-93 and highlights that share of Engineering exports in all India exports increased from $0.5 \%$ in $1956-57$ to $15.3 \%$ in 1992-93. The paper identifies stiff competition from Taiwan, South Korea and China as the major threat to Engineering export. Time lag between the announcement of policies and their implementation or piecemeal sanctioning of benefits to exporting community also retarded our engineering exports, the author opines. Other internal problems identified by the author are: inadequate infrastructural facilities, high cost of industrial inputs, domestic demand pull, outdated method of working, smaller size of manufacturing units, absence of credibility and lack of export culture.

Singha and Gayatri (2010) make an attempt to review the promotion-oriented industrial policies of Indian Engineering industry and also trace the industrial growth 
from 1950-51 onwards. The paper concludes that Indian engineering industry has exhibited growth and diversification under the various policy responses, which the government of India undertook from time from to time.

Muthusamy and Kargalakshmi (2015) analyse the performance of Engineering Industry in India for the period 2010-11 to 2014-15. The study points out that Indian engineering industry has witnessed an unprecedented growth in the past few years as a result of increased investment in infrastructure development and industrial production. India has a diversified industrial machinery and capital base competent of catering to complex requirements and demands for an entire range of industrial machinery. The authors conclude that India's engineering sector has significant potential for future growth, in manufacturing as well as services.

\subsection{Analysis of Trends in India's Engineering Exports}

\subsection{Contribution to the export effort}

Engineering industry is now exporting an increasingly wide variety of light, medium and heavy engineering goods. Engineering goods export has grown by leaps and bounds from a mere 5.16 crores Rupees (US\$ 10 million) in 1956-57 to an impressive and all time high of 447049.00 crores Rupees (US\$ 70.7 billion ) in 2014-15 (Table 3).

Table 3: Engineering Export Vis-a-vis Total Export

(Value in Rs Crores)

\begin{tabular}{|c|c|c|c|c|}
\hline Year & $\begin{array}{l}\text { Total } \\
\text { Export }\end{array}$ & $\begin{array}{l}\text { Engineering } \\
\text { Export }\end{array}$ & $\begin{array}{l}\% \text { share of } \\
\text { Engineering Export } \\
\text { to Total export }\end{array}$ & \begin{tabular}{ll} 
Annual & \multicolumn{2}{c}{ Average } \\
Growth Rate of \\
Engineering export
\end{tabular} \\
\hline $2002-03$ & 255799.55 & 43625.94 & 17.05 & 31.42 \\
\hline 2003-04 & 294143.23 & 56802.83 & 19.31 & 30.20 \\
\hline 2004-05 & 375339.50 & 73800.39 & 20.68 & 29.92 \\
\hline $2005-06$ & 456417.9 .0 & 96156.90 & 21.06 & 30.29 \\
\hline $2006-07$ & 571779.30 & 133790.10 & 23.39 & 39.13 \\
\hline $2007-08$ & 655863.50 & 150434.80 & 22.9 & 12.40 \\
\hline 2008-09 & 840755.10 & 217482.00 & 25.86 & 44.56 \\
\hline $2009-10$ & 845534.00 & 159499.00 & 18.86 & -26.66 \\
\hline $2010-11$ & 1142922.00 & 229084.00 & 20.04 & 43.62 \\
\hline $2011-12$ & 1465959.00 & 287170.00 & 19.50 & 25.35 \\
\hline $2012-13$ & 1634318.80 & 321919.00 & 19.69 & 12.10 \\
\hline 2013-14 & 1905011.10 & 387687.00 & 20.30 & 20.42 \\
\hline 2014-15 & 1897026.00 & 447049.00 & 23.56 & 15.31 \\
\hline
\end{tabular}

Sources: Director General of Commercial Intelligence and Statistics (DGCI\&S), Calcutta; Engineering Goods Export Promotion Council, Calcutta; Centre for Monitoring Indian Economy: Foreign Trade and Balance of Payments, July 2005; RBI Handbook of Statistics on Indian Economy, 2014-15. 
The engineering sector has grown manifold in Rupee/dollar terms over the years and has been one of the most dynamic elements of Indian exports. In the period before the global financial crisis 2002-08, engineering exports recorded the highest annual average growth of $31.13 \%$. However, the Global financial crisis was a big blow to the Engineering export. The export recorded a negative growth rate of 26 percent during 2009-10 and thereafter annual average growth rate in the post global financial slipped down to 23.36 percentage during 2010-15. The progress of export of Engineering goods vis-à-vis total export from the country for 2002-15 can be better judged from Table 3 and Figure 2.

Figure 2: Engineering Goods Export 2002-15

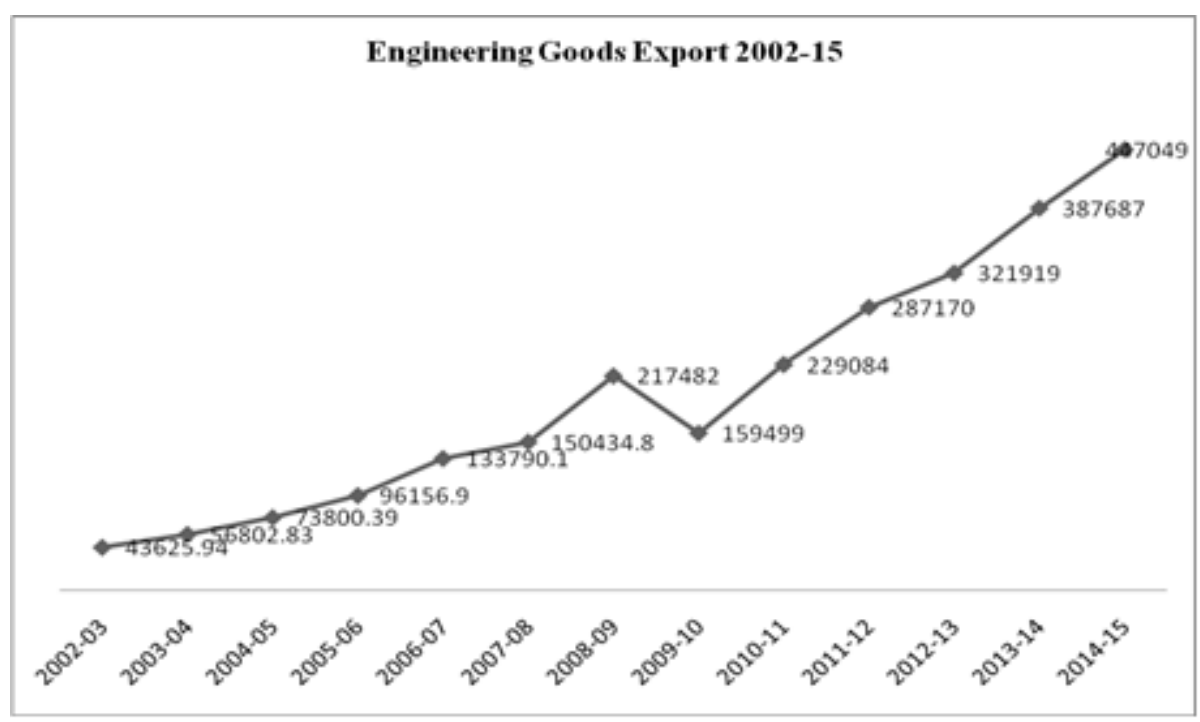

Source: same as Table 3

\subsection{Average annual growth rate}

Table 4 shows that the average annual growth rate of engineering export in the pre-global crisis period was higher than post-global financial crisis period. This shows the clear impact of crisis on engineering goods export from India.

Table 4: Average Annual Growth Rate in Pre and Post Global Crisis Period

\begin{tabular}{|l|l|l|}
\hline & $\begin{array}{l}\text { Pre Global Crisis } \\
\mathbf{( 2 0 0 2 - 0 8 )}\end{array}$ & $\begin{array}{l}\text { Post Global Crisis } \\
\mathbf{( 2 0 1 0 - 2 0 1 5 )}\end{array}$ \\
\hline Average Annual Growth Rate & 31.13 & 23.36 \\
\hline
\end{tabular}

Source: Calculated by the author on the basis of Table 3 


\subsection{Regression analysis}

In order to statistically cross check our growth rate and see if there any structural break in the data during this period due to global financial crisis, we have run a dummy variable regression model as follows:

$$
Y_{t}=\beta_{1}+\beta_{2} D_{t}+U_{t}
$$

where $\mathrm{Y}=$ Engineering Export $\mathrm{D}=$ Dummy Variable. Dummy variable assume value one for post-global crisis year and zero for pre-global crisis year. The null hypothesis tested was that there is no structural break in the Engineering Export. The results are shown in Table 5. The estimated regression is statistically significant (as indicate by $\mathrm{p}$ value) implying that there is a structural break during the crisis period and the crisis had an impact on engineering exports.

Table 5: Regression Results

\begin{tabular}{|c|r|r|r|r|}
\hline Variable & Coefficient & Std. Error & t-Statistic & Prob. \\
\hline C & 110299.0 & 31631.45 & 3.487004 & 0.0051 \\
\hline DUMMY & 195102.3 & 46560.23 & 4.190322 & 0.0015 \\
\hline
\end{tabular}

R-squared 0.614830

Adjusted R square 0.571894

Dependent Variable: Engineering Export

Sample 2002-14

\subsection{Composition of Engineering Goods Export} follows:

The key categories of Engineering Exports in 2014-15 (Figure 3) were as

- Transport equipment (which includes Auto \& auto component including Aircraft and ship boats) is the leading contributor to engineering exports accounting for 34.5 per cent of the total engineering exports in FY 15.

- Iron \& Steel and products made of Iron \& Steel have accounted around 22.9 per cent market share while industrial machinery including electrical machinery accounted 21.9 per cent of the total engineering exports in FY15.

- Others commodities includes Medical and Scientific instruments, Hand tools \& Cutting tools, Bicycle parts, Office equipments, Prime Mica \& Mica Products etc. accounted 8.7 per cent of the total engineering exports in FY15(Adapated from Ibef.org)

If we compare this performance with 1960-61, we can understand that there has been marked shift and significant changes in composition of engineering export over the last 6 decades. The capital goods sector in 1960-61 accounted only 12.46 per cent which 
now account for major chunk of engineering goods export implying a welcome step and a major structural change in the export of engineering goods over the years. More significantly the share of consumer durables also drastically declined in the overall engineering export during this period.

Figure 3: Composition of Engineering Goods Export, 2014-15

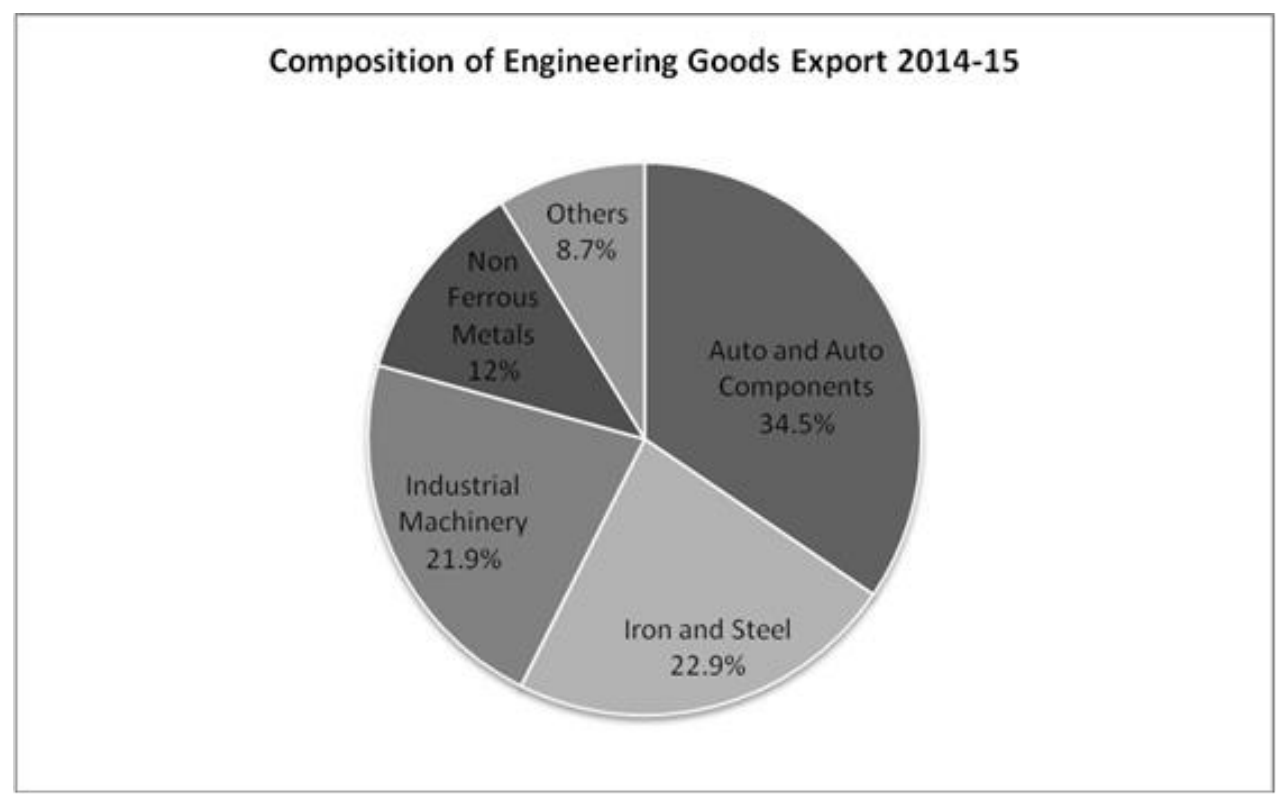

Source: Prepared by Author by using data from www.ibef.org

\subsection{Destination of Engineering Goods Export}

Indian Engineering products are exported to a large number of developed and developing countries of the world. A close look at the destination of Indian Engineering export shows that there has been substantial diversification in the destination of export. Up to 1980s, the major destination of India's Engineering export was Asia and Africa. However, in the early eighties the trend has changed substantially with share of Europe, Australia, and North America increasing substantially. During the eighties East European countries emerged as a big market for Indian Engineering product, whose share has declined after the disintegration of erstwhile Soviet Union. Fortunately, this short fall has been compensated by larger export to developed countries (EEPC). The 
region wise /country wise export of Indian Engineering goods between 1956-57 and 2013-14 is shown in Table 6.

Table 6: Destination of Engineering Export: Region wise 1956-57 to 2013-14

\begin{tabular}{|l|l|l|}
\hline \multicolumn{2}{|c|}{ (Value in Rs Crores) } \\
\hline Region & $\mathbf{1 9 5 6 - 5 7}$ & \multicolumn{1}{c|}{$\mathbf{2 0 1 3 - 1 4}$} \\
\hline Asia & $\begin{array}{l}3.76 \\
(73.9 \%)\end{array}$ & $\begin{array}{l}116306.10 \\
(30 \%)\end{array}$ \\
\hline Africa & 1.2 & $\begin{array}{l}46522.44 \\
(12 \%)\end{array}$ \\
\hline Europe & $(23.3 \%)$ & $\begin{array}{l}69783.66 \\
(18 \%)\end{array}$ \\
\hline North America & NEG & $\begin{array}{l}46522.44 \\
(12 \%)\end{array}$ \\
\hline Australia & NEG & $\begin{array}{l}5815.30 \\
(1.5 \%)\end{array}$ \\
\hline Total & & 387687.00 \\
(including others) & NEG & $(100 \%)$ \\
\hline
\end{tabular}

Sources: EEPC, RBI Handbook on Indian Economy

\subsection{Engineering Exports; The Road Ahead}

\subsection{Problems of engineering export}

Like any other items of export engineering export also faces numerous challenges such as:

i) Stiff competition from other countries such as China, Mexico, Hungary, Czechoslovakia and Korea.

ii) Technological problems.

iii) High cost of industrial inputs.

iv) Barriers by developed countries.

v) High transaction cost.

\subsection{Strategies for promotion of engineering export}

In the light of the discussion of numerous problems faced by engineering export, it is necessary to evolve a scientific strategy, which should aim not only at consolidating the gains achieved so far but also in promoting higher export of engineering products. Formulation of such strategy will enable Engineering industry to sustain the extreme 
competition in international market. Various measures envisaged under this strategy are listed below:

i) Market Diversification Strategy: A market diversification strategy based on the changing dynamics of growth in the world economy is necessary to ensure sustained growth of exports. The demand in the traditional markets of the developed western world, North America and Europe, is projected to be relatively sluggish due to slowing output expansion in these economies. Against this, emerging economies are expected to grow at about $6.5 \%$.We would have to focus on markets in Asia (including ASEAN), Africa and Latin America. We must establish new beachheads and strengthen our presence in newly opened up markets. This should be done without jeopardizing existing market" (Ministry of Commerce, 2014).

ii) Setting up of more Engineering Export Processing zones, Special Economic Zones and Export Oriented Units: At present India have 13 SEZs for promotion of Engineering Export. They are located at 1)Ranga Reddy, 2) Nalgonda (Andhra Pradesh) 3)Hazira 4) Gandhi Nagar 5) Ahmedabad ) two at Ahmedabad) 6) Vadodara 7) Amreli (Gujarath) 8) Sonepat two ar Sonepat) 9)Gurgaon (Haryana) 10) Shimoga 11) Manglore (Karnataka). (SEZ India, Aranca Research Developer, Adopted from Ibef.org).More such SEZs and EOUs need to be established for furtherance of engineering export.

iii) Technology up-gradation is also need of the hour. Without adopting state of the art latest technology engineering export cannot sustain international competition. New Industrial Policy 1991 and Export import Policy from time to time give various incentives in this regard.

iv) Brand Building and Image: To establish greater credibility and acceptance of our critical export products and sectors in foreign markets, we would strengthen efforts to build up a brand image for important Indian exports, and promote a thrust for quality upgradation. Domestic standards for export related products would be raised, assurances put in place of quality enforcement through appropriate agencies, such as BIS, EIC, etc., and expanded certification of export products encouraged, where needed. To back up these efforts, a Brand India promotion campaign for key export products would be supported. More than 2,500 firms in the engineering sector have ISO 9000 accreditation and companies are now increasingly focusing on R\&D and product development with the entry of international companies. (ibef.org)

v) Free Trade Area/ Preferential Trade Agreement (FTA/PTA): We must explore the possibility of setting up Free Trade Area/Preferential Trade Agreements with other countries where our export has largest concentrations. For instance, FTA/PTA with Brazil and Mexico as Latin America represent a fairly large latent market for Indian auto components will provide a fillip to our Engineering export. 


\subsection{Promotional Role of EEPC in engineering export}

Our discussion of the performance of Engineering export becomes incomplete without a discussion on the role of EEPC (Engineering Export Promotion Council) in promoting Engineering export. EEPC plays an outstanding role in the export activities of Engineering Goods. It sponsors on a regular basis visit on multi-product Trade Delegation to identified market overseas to foster closer cooperation and to promote strategic alliances and Joint Ventures with overseas companies. The proposal for the delegation in both the directions are finalized on the basis of detailed interaction with the trade and industry and also with the full support of the Ministry of Commerce, Government of India.

In the present scenario of global trade, emergence of trading block has necessitated the need for increased awareness on the India's capabilities in the engineering sector and for establishing the "Made in India" brand image in the overseas markets. With this in view, the Council's Publicity Programme includes not only the release of advertisement in leading dailies, but also distribution of video films on the Indian engineering industry to trade and industry associations in the identified overseas thrust markets. EEPC also brings out full-fledged supplement in reputed newspaper and magazines of world repute coinciding with major events and also distributes C.D. ROMs containing directory of members to leading Buying Houses, Chambers, Associations, and Trade Bodies. It also brings out on a regular basis product specific catalogues highlighting the major manufacturers of such products, standard adopted, export destination and other details in order to instil confidence to the buyers on the reliability. The foreign offices of the Council, on the other hand, are spearheading Council's direct publicity in overseas markets by exhaustive mailing campaign of promotional literatures, information on sources of supply and developments( www.eepc.com)

\subsection{Conclusion}

Engineering Sector thus has a pride of place in Indian economy in terms of its contribution to output, employment and export. The sector remains healthy because of the Government's continued thrust on infrastructure development both at the Central and State level. There has been marked shift and changes in the composition and destination of Indian Engineering Export over the years. Engineering Sector has made its presence felt in the developed markets like US and European Union implying our strength and capability to deliver quality products and face international competition. Engineering services export (ESO) is also emerging in a big way which will provide new direction and opportunities for future growth of engineering sector in India. 
102 | PRAGATI: Journal of Indian Economy, Volume 3, Issue 1

\section{References}

Ahum Duk, Kong. ( 2001). Trade policy and its implications A comparative study of India and Korea. Foreign Trade Review, XXXVI(1\&2), April-September.

Arora, D.S. (1993). India's engineering exports. Foreign Trade Review, XXVII(2), April -June.

Balassa, B. (1978). Exports and economic growth: Further evidence. Journal of Development Economics, 5(2): 181-189.

Centre for Monitoring Indian Economy. (1995). Foreign trade and balance of payments.

Centre for Monitoring Indian Economy. (2005). Foreign trade and balance of payments.

Chow, P.C.Y. (1987). Causality between export growth and industrial development. Journal of Development Economics, 26: 55-63.

Engineering Export Promotion Council. (1979). Growing protectionism in developed countries- Implications for india's exports of engineering products. Foreign Trade Review, XIV(2): July- Sep.

Engineering Export Promotion Council. (2005). Strategy paper for the growth of Engineering export 2005-06 to 2009-10. Prepared by A.F Ferguson and Company (available at www.eepcindia.org)

Engineering Export Promotion Council. (various issues). Export Statistics.

Ghartey, E.E. (1993). Causal relationship between exports and economic growth: Some empirical evidence in Taiwan, Japan and the U.S. Applied Economics, 25: 1145-1152.

Government of India, Ministry of Commerce and Industry, DGCI\&S. (2014). Export Statistics.

Government of India, Ministry of Finance and Company Affairs. (various issues). Economic Survey. 
Kareem, Abdul P. (1989). Import substitution in indian engineering industry, 1970-84. Artha Vijnana, 31(4): 333-347.

Keesing, D. B. (1967). Outward-looking policies and economic development. Economic Journal, 77(306): 303-320.

Keesing, D.B. (1979). Trade policies for developing countries. World Bank Staff Working Paper No. 353, August.

Krueger, A. (1978). Foreign trade regimes and economic development: Liberalisation, Attempt and Consequences. NBER, New York.

Michaely, M (1977). Exports and growth: An empirical investigation. Journal of Development Economics, 4(1): 49 - 53.

Muthusamy A \& S Karpakalakhsmi. (2015). A study on production and export performance of engineering goods exports in India. Indian Journal of Applied Research, 5(6): June.

Nayyar, Depak. (1976). India's exports in the 1970's. Economic and Political Weekly, May 15.

Riezman, R G., C.H. Whiteman, \& P. M. Summers. (1996). The engine of growth or its handmaiden? A time series assessment of export led growth. Empirical Economics, 21(1): 77 - 110 .

Singha, Rajdeep \& Gayathri, K. (2010). Government policy and performance: A study of Indian engineering industry. Working paper no. 253, ISEC Banglore.

UNCTAD. (2013). Impact of the global slowdown on India's exports and employment.

\section{Weblinks}

www. dgft.gov.in

www.eepc.com

www.ibef.org

www.worldbank.org 